\title{
Tanggungjawab Ahli Waris Dan Kewenangan Majelis Pengawas Notaris Dalam Penyelesaian Protokol Minuta Hilang (Studi tentang Notaris yang Meninggal Dunia)
}

\section{Riky Rustam}

Fakultas Hukum Universitas Islam Indonesia Yogyakarta Indonesia Jln. Taman Siswa No. 158 Yogyakarta Indonesia 154101313@uii.ac.id

\begin{tabular}{|c|c|}
\hline Key Word: & Abstract \\
\hline $\begin{array}{l}\text { Heirs; } \quad \text { missing } \\
\text { minute of protocol; } \\
\text { notary supervisory } \\
\text { council }\end{array}$ & $\begin{array}{l}\text { This study aims to raise the issue on the position of the Minute of Protocol of Notary } \\
\text { Deed as a State Archive as stipulated in the Archives Act, analyze the responsibility } \\
\text { of the heirs of a Notary who died for the missing Minute of Protocol and explain the } \\
\text { authority of the Regional Supervisory Council to resolve the missing Minute of } \\
\text { Protocol after the notary's death. The method used in this research is normative } \\
\text { study by collecting data through library research, using a normative and conceptual } \\
\text { approaches as well as qualitative descriptive analysis. The results of this research } \\
\text { conclude that the Notary Protocol is a state archive based on the provisions of the } \\
\text { Notary Position Act, but not the archive criteria referred to in the Archives Law. } \\
\text { The heirs are responsible to the parties who make an authentic deed to the Notary, } \\
\text { this responsibility is based on the provisions of Article } 1365 \text { of the Criminal Code on } \\
\text { Unlawful Acts. Then, the Notary Supervisory Council does not have the authority } \\
\text { to give sanctions to heirs who eliminate the Notary Protocol. In the event that the } \\
\text { Notary protocol is missing or incomplete, the Regional Supervisory Council shall } \\
\text { make a detailed and complete report on this matter. }\end{array}$ \\
\hline
\end{tabular}

Kata-kata Kunci:
Ahli waris; majelis
pengawas notaris;
protokol minuta
hilang

\begin{abstract}
Abstrak
Penelitian ini bertujuan untuk mengemukakan permasalahan mengenai kedudukan Protokol Minuta Akta Notaris sebagai Arsip Negara sebagaimana ketentuan Undang-Undang Kearsipan, menganalisa mengenai pertanggungjawaban ahli waris dari Notaris yang meninggal dunia atas Protokol Minuta yang hilang dan menjelaskan kewenangan Majelis Pengawas Daerah untuk menyelesaikan Protokol Minuta hilang setelah meninggalnya Notaris. Metode yang dipakai dalam penelitian ini adalah penelitian normatif dengan mengumpulan data secara studi pustaka (library research), menggunakan pendekatan norma dan pendekatan konseptual serta analisis secara deskriptif kualitatif. Hasil penelitian ini menyimpulkan bahwa protokol Notaris merupakan arsip negara berdasarkan ketentuan UndangUndang Jabatan Notaris, namun bukan kriteria arsip yang dimaksud dalam Undang-Undang Kearsipan. Ahli waris bertanggungjawab kepada para pihak yang membuat akta autentik kepada Notaris, tanggungjawab ini adalah berdasarkan ketentuan Pasal 1365 KUHPerd tentang Perbuatan Melawan Hukum. Kemudian, Majelis Pengawas Notaris tidak memiliki kewenangan untuk memberikan sanki kepada ahli waris yang menghilangkan Protokol Notaris. Dalam hal terjadi protokol Notaris yang hilang atau tidak lengkap, maka Majelis Pengawas Daerah membuat berita acara mengenai hal itu secara terperinci dan lengkap.
\end{abstract}

\section{Pendahuluan}

Notaris merupakan pejabat umum yang salah satu kewenangan utamanya adalah membuat akta autentik. Dalam pembuatan akta tersebut harus memperhatikan bentuk 
dan tata cara yang telah ditetapkan oleh undang-undang sebagaimana yang diatur Undang-Undang Nomor 30 Tahun 2004 tentang Jabatan Notaris (selanjutnya disebut Undang-Undang Jabatan Notaris) dan Undang-Undang Nomor 02 Tahun 2014 tentang Perubahan Undang-Undang Nomor 30 Tahun 2004 tentang Jabatan Notaris (selanjutnya disebut Undang-Undang Jabatan Notaris Perubahan) sebagai pedoman bagi notaris dalam melaksanakan tugas dan kewenangannya. ${ }^{1}$

Kewajiban Notaris untuk mentaati peraturan perundang-undangan yang berlaku tersebut adalah sebagai perwujudan bahwa akta autentik mempunyai beberapa batasan, yaitu:2

1. Undang-undang telah mengatur pejabat lain untuk membuat akta tanpa ada perkecualian.

2. Bahwa notaris harus membuat akta mengenai semua perbuatan, perjanjian dan penetapan yang diharuskan oleh suatu peraturan umum atau yang sesuai dengan kehendak para pihak.

3. Berkaitan dengan subjek hukum (baik orang atau badan hukum), untuk kepentingan siapa akta dibuat atau dikehendaki.

4. Berkaitan dengan tempat kedudukan dan wilayah jabatan, notaris berwenang terhadap tempat di mana akta dibuat.

5. Berkaitan dengan waktu pembuatan akta, notaris harus menjamin kepastian hari, tanggal dan jam yang tercantum dalam akta.

Salah satu kewajiban itu adalah mencatat seluruh akta yang dibuat oleh Notaris yang bersangkutan dan mengisi buku daftar akta tanpa sela-sela kosong setiap harinya. Sebagaimana Pasal 58 ayat (2) Undang-Undang Jabatan Notaris menjelaskan bahwa Notaris wajib mencatat semua akta yang dibuatnya tanpa sela-sela kosong dan setiap bulan ditutup dengan garis merah. Dalam satu hari berapa akta yang dibuat oleh Notaris harus selalu dicatat dalam buku daftar akta.

Adanya kewajiban Notaris untuk membuat buku daftar akta tersebut juga disertai dengan kewajiban Notaris untuk membuat minuta akta sebagai bagian dari Protokol Notaris. Sebagaimana ketentuan Pasal 16 ayat (1) huruf b Undang-Undang Jabatan Notaris Perubahan menyebutkan bahwa dalam menjalankan jabatannya, Notaris wajib membuat akta dalam bentuk Minuta Akta dan menyimpannya sebagai bagian dari Protokol Notaris. Minuta Akta adalah asli akta yang mencantumkan tanda tangan para penghadap, saksi, dan Notaris, yang disimpan sebagai bagian dari Protokol Notaris. ${ }^{3}$ Protokol Notaris yang dimaksud dalam hal ini adalah kumpulan dokumen yang merupakan arsip negara yang harus disimpan dan dipelihara oleh Notaris sesuai dengan ketentuan peraturan perundang-undangan. ${ }^{4}$

Kewajiban menyimpan Protokol Notaris tidak hanya berlaku selama Notaris tersebut masih hidup. Jika seorang Notaris tidak dapat menjalankan kewajibannya sebagai Notaris bahkan dalam dalam Notaris meninggal dunia, Undang-Undang tetap

\footnotetext{
${ }^{1}$ Habib Adjie, Hukum Notaris Indonesia, Refika Aditama, Bandung, 2008, hlm. 45

${ }^{2}$ Habib Adjie, Sanksi Perdata dan Administratif Terbadap Notaris Sebagai Pejabat Publik, PT.Refika Aditama, Bandung, 2008, hlm. 56

${ }^{3}$ Pasal 1 angka (8) Undang-Undang Jabatan Notaris Perubahan

${ }^{4}$ Pasal 1 angka (13) Undang-Undang Jabatan Notaris Perubahan
} 
mewajibkan seluruh Minuta akta sebagai Protokol Notaris tersebut tetap disimpan dengan cara mengalihkan Protokol Notaris kepada Notaris lain. Sebagaimana ketentuan Pasal 62 Undang-Undang Jabatan Notaris menentukan bahwa:

Penyerahan Protokol Notaris dilakukan dalam hal Notaris:
a. Meninggal dunia;
b. Telah berakhir masa jabatannya;
c. Minta sendiri;
d. Tidak mampu secara rohani dan/atau jasmani untuk melaksanakan tugas jabatan sebagai Notaris secara terus menerus lebih dari 3 (tiga) tahun;
e. Diangkat menjadi pejabat negara;
f. Pindah wilayah jabatan;
g. Diberhentikan sementara; atau
h. Diberhentikan dengan tidak hormat.

Penyerahan Protokol Notaris di atas harus dilakukan paling lama 30 (tiga puluh) hari dengan pembuatan berita acara penyerahan Protokol Notaris yang ditandatangani oleh yang menyerahkan dan yang menerima Protokol Notaris. Dalam hal Notaris meninggal dunia, penyerahan Protokol Notaris dilakukan oleh ahli waris Notaris kepada Notaris lain yang ditunjuk oleh Majelis Pengawas Daerah. ${ }^{5}$ Meskipun demikian, setelah dilakukan penyerahan Protokol Notaris, Notaris yang membuat akta tetap bertanggungjawab atas akta yang dibuatnya itu, sebagaimana ketentuan Pasal 65 Undang-Undang Jabatan Notaris Perubahan yang menentukan bahwa Notaris, Notaris Pengganti, dan Pejabat Sementara Notaris bertanggung jawab atas setiap Akta yang dibuatnya meskipun Protokol Notaris telah diserahkan atau dipindahkan kepada pihak penyimpan Protokol Notaris.

Kewajiban ahli waris untuk menyerahkan Protokol Notaris dalam hal Notaris meninggal dunia lebih lengkap diatur oleh Pasal 35 Undang-Undang Jabatan Notaris Perubahan, yang menyatakan bahwa:

(1) Apabila Notaris meninggal dunia, suami/istri atau keluarga sedarah dalam garis lurus keturunan semenda sampai derajat kedua wajib memberitahukan kepada Majelis Pengawas Daerah.

(2) Pemberitahuan sebagaimana dimaksud pada ayat (1) disampaikan dalam waktu paling lama 7 hari kerja.

(3) Apabila Notaris meninggal dunia pada saat menjalankan cuti, tugas jabatan Notaris dijalankan oleh Notaris Pengganti sebagai Pejabat Sementara Notaris paling lama 30 hari terhitung sejak tanggal Notaris meninggal dunia.

(4) Pejabat Sementara Notaris menyerahkan Protokol Notaris dari Notaris yang meninggal dunia kepada Majelis Pengawas Daerah paling lama 60 hari terhitung sejak tanggal Notaris meninggal dunia.

(5) Pejabat Sementara Notaris sebagaimana dimaksud pada ayat (3) dan ayat (4) dapat membuat Akta atas namanya sendiri dan mempunyai Protokol Notaris.

Ketentuan Pasal 35 Undang-Undang Jabatan Notaris Perubahan tersebut di atas dengan tegas menunjukan bahwa Protokol Notaris wajib disimpan dan dijaga oleh Notaris dan ahli warisnya, jika Notaris yang bersangkutan meninggal dunia maka ahli

${ }^{5}$ Pasal 63 Undang-Undang Jabatan Notaris Perubahan 
waris harus segera memberitahukan hal itu kepada Majelis Pengawas Daerah untuk kemudian diambil tindakan sesuai dengan ketentuan peraturan perundang-undangan.

Dalam praktik, ditemukan suatu kasus dimana setelah seorang Notaris meninggal dunia, seluruh Protokol Notaris yang ada dijual oleh Ahli Waris Notaris dikarenakan ketidaktahuan Ahli Waris mengenai kewajiban untuk menyimpan Protokol Notaris tersebut. Secara normatif, keadaan ini tentu saja telah melanggar ketentuan Pasal 62 Undang-Undang Jabatan Notaris dan Pasal 35 Undang-Undang Jabatan Notaris Perubahan sebagaimana yang telah dijelaskan di atas. Meskipun demikian, UndangUndang Jabatan Notaris dan Undang-Undang Jabatan Notaris Perubahan sama sekali tidak menentukan sanksi atas dilanggarnya Pasal 62 Undang-Undang Jabatan Notaris dan Pasal 35 Undang-Undang Jabatan Notaris Perubahan tersebut.

Keadaan ini mengakibatkan kekosongan hukum yang menimbulkan problematika hukum bagi seluruh pihak yang terkait dengan akta dan Notaris tersebut, mulai dari para penghadap yang telah membuat akta, para ahli waris, sampai dengan Majelis Pengawas Daerah yang memiliki wewenang atas Protokol Notaris tersebut. Bagi para penghadap, masalah akan terjadi jika akta yang telah dibuat menimbulkan sengketa hingga ke Pengadilan, pembuktian keautentikasian akta akan terkendala dikarenakan tidak adanya minuta akta yang dapat dihadirkan di hadapan majelis Hakim. Terlebih lagi dalam beberapa kasus pernah juga terjadi staff Notaris membuatkan akta untuk para pihak tanpa sepengetahuan Notaris yang bersangkutan, sehingga ada salinan akta namun tidak ada minuta akta dari akta tersebut.

Bagi para Ahli Waris, tindakan menjual Protokol Notaris adalah perbuatan yang melanggar Undang-Undang Jabatan Notaris, namun menjadi kabur bentuk kesalahan apakah yang dapat dituntut kepada ahli waris atas perbuatannya tersebut. Belum ada ketentuan yang mengatur secara tegas mengenai pertanggungjawaban ahli waris Notaris dalam keadaan seperti ini, apakah dapat digugat secara keperdataan atau bahkan dapat dituntut secara pidana juga tidak jelas ketentuan yang mengaturnya. Hal ini terkait ketentuan yang diatur dalam Undang-Undang Jabatan Notaris hanya berlaku bagi Notaris dan tidak dapat dialihkan kesalahannya kepada pihak lain, di sisi lain dalam hukum pidana mengenal asas legalitas dimana tidak bisa suatu perbuatan dipidana sebelum ada ketentuan yang melarangnya terlebih dahulu.

Jika definisi Protokol Notaris sebagaimana disebutkan Pasal 1 angka (13) UndangUndang Jabatan Notaris Perubahan bahwa "Protokol Notaris yang dimaksud dalam hal ini adalah kumpulan dokumen yang merupakan arsip negara yang harus disimpan dan dipelihara oleh Notaris sesuai dengan ketentuan peraturan perundang-undangan" dikaitkan dengan Undang-Undang Nomor 43 Tahun 2009 tentang Kearsipan (selanjutnya disebut Undang-Undang Kearsipan), kedudukan Protokol Notaris sebagai arsip negara juga menimbulkan pertanyaan tersendiri. Dalam Undang-Undang Kearsipan tidak ada ketentuan yang secara tegas menyatakan bahwa Protokol Notaris adalah salah satu arsip yang diatur oleh Undang-Undang Kearsipan tersebut. Karakter yang dimiliki oleh Protokol Notaris juga memiliki perbedaan dengan arsip yang ditentukan oleh UndangUndang Kearsipan, yang dapat dijabarkan sebagai berikut: 
1. Arsip yang ditentukan oleh Undang-Undang Kearsipan dikelola dan dibiayai menggunakan anggaran Negara, sedangkan Protokol Notaris dikelola dan dibiayai sendiri oleh Notaris.

2. Masa penyimpanan arsip yang ditentukan oleh Undang-Undang Kearsipan memiliki batas waktu dimana jika masa tersebut telah terlewati maka arsip yang bersangkutan menjadi terbuka atau bahkan dapat dimusnahkan, sementara Protokol Notaris harus disimpan dalam waktu yang sangat panjang bahkan setelah Notaris tersebut meninggal dunia.

Adanya perbedaan karakter ini juga menyebabkan adanya kekosongan hukum tersendiri dari aspek kedudukan Protokol Notaris sebagai arsip negara untuk menentukan pertanggungjawaban ahli waris yang menghilangkan Minuta Akta Notaris dalam kedudukan sebagai arsip negara tersebut.

Sementara bagi Majelis Pengawas Daerah, keadaan ini juga menjadi problematika tersendiri mengenai cara penyelesaiannya terkait tidak adanya aturan yang jelas mengenai keadaan tersebut. Sebagai Lembaga yang memiliki kewenangan untuk menunjuk Notaris yang akan bertindak sebagai pemegang Protokol Notaris yang meninggal dunia sebagaimana ketentuan Pasal 23 ayat (2) huruf b Peraturan Menteri Hukum dan Hak Asasi Manusia Nomor 40 Tahun 2015 tentang Susunan Organisasi, Tata Cara Pengangkatan Anggota, Pemberhentian Anggota, dan Tata Kerja Majelis Pengawas (Selanjutnya disebut Permenkumham 40 Tahun 2015), Majelis Pengawas Daerah tidak dapat melaksanakan kewenangannya untuk menyerahkan protokol notaris tersebut kepada Notaris lain dikarenakan hilangnya protokol yang akan diserahkan tersebut.

Apakah yang dapat dilakukan oleh Majelis Pengawas Daerah untuk menyelesaikan keadaan ini juga belum ada ketentuan yang jelas. Terlebih lagi Pasal 2 Peraturan Menteri Hukum dan Hak Asasi Manusia Nomor 15 Tahun 2020 tentang Tata Cara Pemeriksaan Majelis Pengawas Terhadap Notaris (Selanjutnya disebut Permenkumham 15 Tahun 2020) menentukan bahwa Majelis Pengawas berwenang melakukan pembinaan dan pengawasan terhadap Notaris serta melakukan pemeriksaan terhadap dugaan pelanggaran perilaku dan pelaksanaan jabatan Notaris. Frase "Notaris" dalam Permenkumham 15 Tahun 2020 di atas kembali memberikan batasan bahwa yang dapat diperiksa oleh Majelis Pengawas hanyalah Notaris dan bukan ahli waris dari Notaris.

\section{Rumusan Masalah}

Berdasarkan latar belakang tersebut di atas, Peneliti ingin menggali lebih dalam mengenai hal-hal sebagai berikut: pertama, apakah Protokol Minuta Akta Notaris dapat diklasifikasikan sebagai Arsip Negara sebagaimana ketentuan Undang-Undang Kearsipan? Kedua, apakah ahli waris dari Notaris yang meninggal dunia dapat dimintai pertanggungjawaban atas Protokol Minuta yang hilang? Ketiga, bagaimanakah kewenangan Majelis Pengawas Daerah untuk menyelesaikan Protokol Minuta hilang setelah meninggalnya Notaris? 


\section{Tujuan Penelitian}

Tujuan penelitian ini adalah untuk: pertama, untuk menganalisa mengenai kedudukan Protokol Minuta Akta Notaris sebagai Arsip Negara sebagaimana ketentuan Undang-Undang Kearsipan. Kedua, untuk menganalisa pertanggungjawaban ahli waris dari Notaris yang meninggal dunia atas Protokol Minuta yang hilang. Ketiga, untuk menjelaskan kewenangan Majelis Pengawas Daerah untuk menyelesaikan Potokol Minuta hilang setelah meninggalnya Notaris.

\section{Metode Penelitian.}

Penelitian ini adalah penelitian hukum normatif atau penelitian hukum kepustakaan yang mengumpulkan data secara studi kepustakaan (library research), karena itu data yang digunakan adalah data sekunder yang terdiri dari bahan hukum primer dan bahan hukum sekunder dengan pendekatan perundang-undangan dan konseptual. Semua bahan hukum yang telah dikumpulkan tersebut akan dianalisis secara deskriptif kualitatif dengan menekankan pada penalaran, yang akan membandingkan antara konsep dan norma yang mengatur tentang kedudukan protokol notaris sebagai arsip negara, pertanggungjawaban ahli waris yang menghilangkan minuta akta Notaris, dan kewenangan Mejelis Pengawas Notaris dalam menyelesaikan Protokol Notaris hilang dari Notaris yang meninggal dunia, sehingga akan ditemukan order of logic dari permasalahan tersebut sebagai kesimpulan dalam penelitian ini.

\section{Hasil Penelitian dan Pembahasan}

\section{Kedudukan Protokol Notaris Sebagai Arsip Negara Berdasarkan Undang- Undang Kearsipan}

Istilah arsip berasal dari Bahasa yunani, yaitu dari kata arche, dan selanjutnya berubah menjadi archea dan kemudian berubah lagi menjadi archeon yang artinya dokumen atau catatan mengenai permasalahan. ${ }^{6}$ Pasal 1 angka (1) Undang-Undang Kearsipan menyebutkan bahwa kearsipan adalah hal-hal yang berkenaan dengan arsip. Ketentuan ini dilanjutkan oleh angka (2) Pasal yang sama yang menentukan bahwa arsip adalah rekaman kegiatan atau peristiwa dalam berbagai bentuk dan media sesuai dengan perkembangan teknologi informasi dan komunikasi yang dibuat dan diterima oleh lembaga negara, pemerintahan daerah, lembaga pendidikan, perusahaan, organisasi politik, organisasi kemasyarakatan, dan perseorangan dalam pelaksanaan kehidupan bermasyarakat, berbangsa, dan bernegara. Dari beberapa pengertian arsip di atas maka dapat disimpulkan bahwa arsip adalah suatu rekaman informasi baik yang tercatat secara tekstual, gambar amaupun audio visual yang dibuat oleh organisasi public maupun privat dan disimpan dengan menggunakan bermacam-macam media. ${ }^{7}$

Agus Sugiarto dan Teguh Wahyono, Manajemen Kerasipan Modern (Dari Konvensional ke Basis Komputer) Edisi Terbaru, Gava Media, Bandung, 2015, hlm. 5

${ }^{7}$ Sofia Rosalin, Manajemen Arsip Dinamis, UB Press, Malang, 2017, hlm. 3 
Pasal 15 ayat (1) Undang-Undang Jabatan Notaris Perubahan menyebutkan bahwa Notaris merupakan pejabat umum yang kewenangan utamanya adalah untuk membuat akta autentik mengenai semua perbuatan, perjanjian dan penetapan yang diharuskan oleh peraturan perundang-undangan dan/atau yang dikehendaki oleh yang berkepentingan untuk dinyatakan dalam akta autentik, menjamin kepastian tanggal pembuatan akta, menyimpan akta, memberikan grosse, salinan dan kutipan akta, semuanya itu sepanjang pembuatan akta itu tidak juga ditugaskan atau dikecualikan kepada pejabat lain atau orang lain yang ditetapkan oleh undang-undang. Kewenangan Notaris tersebut juga dilengkapi dengan kewajiban untuk menyimpan dan memelihara akta yang telah dibuatnya selama menjalankan tugas dan jabatannya sebagai Notaris sebagaimana ketentuan Pasal 16 ayat (1) huruf b Undang-Undang Jabatan Notaris Perubahan di atas.

Jika dikaji secara mendalam, ternyata ada perbedaan yang cukup siginfikan diantara keduanya. Berikut beberapa perbedaan antara Undang-Undang Kearsipan dengan Undang-Undang Jabatan Notaris:

Tabel Perbedaan Arsip dalam Undang-Undang Kearsipan dan Protokol Notaris sebagai Arsip Negara dalam Undang-Undang Jabatan Notaris

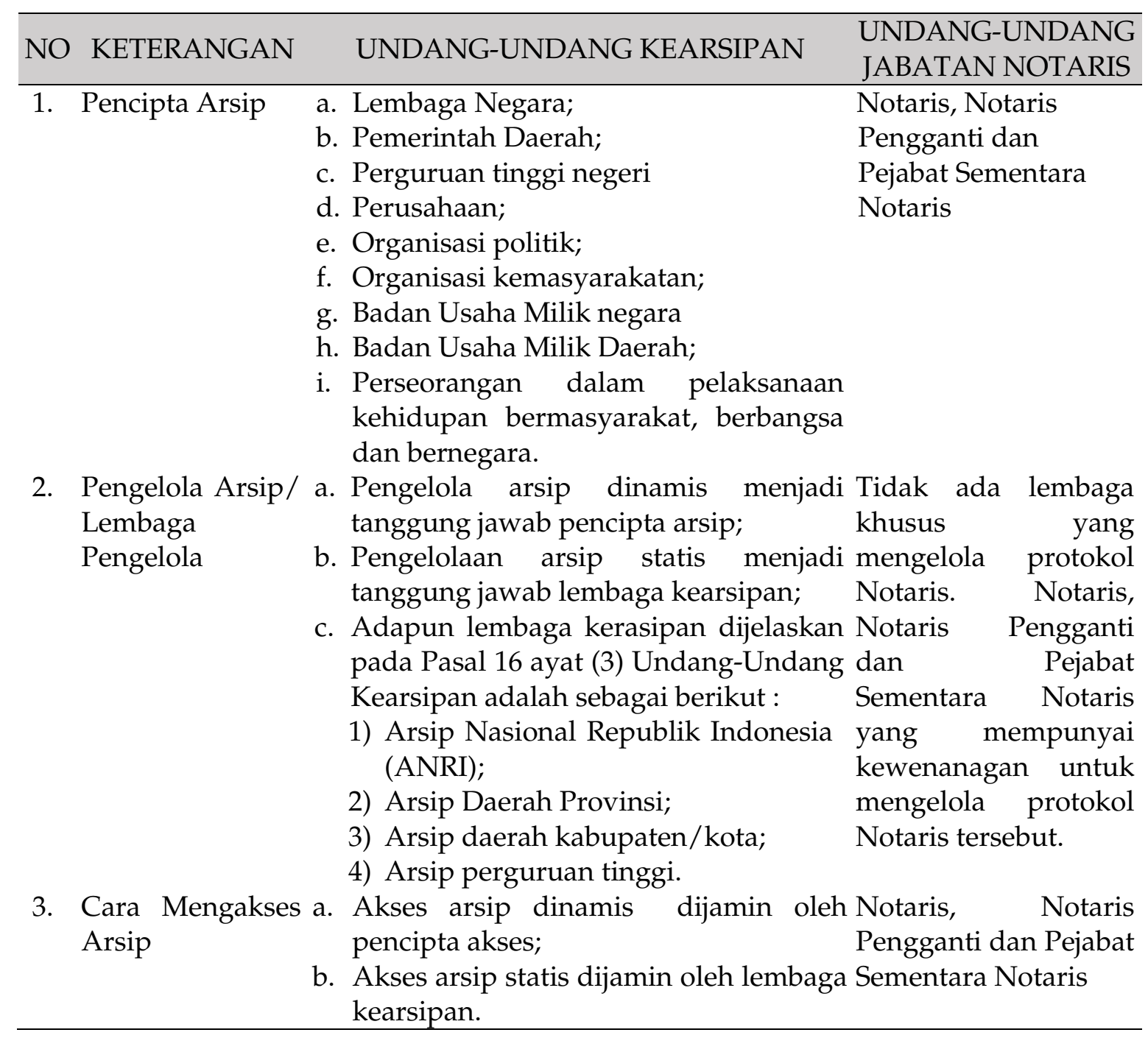


4. Masa Retensi Minimal 10 (sepuluh) tahun, untuk arsip Tidak ada masa Arsip statis disimpan selama 25 (dua puluh retensi, meskipun lima) tahun dan baru terbuka setelah Notaris tersebut melewati masa tersebut. Arsip statis ini meninggal, Protokol terkait kesejarahan. Notaris tetap harus disimpan oleh pemegang protokol tersebut.

5. Pendanaan Diambilkan dari APBN atau APBD Dari Notaris sendiri tanpa ada campur tangan dari Pemerintah

6. Pemusnahan Dikenal adanya kegiatan Penyusutan Tidak mengenal arsip arsip yaitu kegiatan pengurangan jumlah pemusnahan karena arsip dengan cara pemindahan arsip wajib dijaga dan inaktif dari unit pengolah ke unit disimpan selamanya. kearsipan, pemusnahan arsip yang tidak memiliki nilai guna, dan penyerahan arsip statis kepada lembaga kearsipan.

Berdasarkan hal-hal tersebut di atas, terlihat bahwa ada perbedaan yang cukup signifikan antara arsip negara yang diatur Undang-Undang Kearsipan dengan Protokol Notaris sebagai arsip negara berdasarkan Undang-Undang Jabatan Notaris. Mulai dari adanya perbedaan mengenai pencipta arsip, pengelolaan arsip atau Lembaga pengelola, cara mengakses arsip, masa retensi arsip, pendanaan pengelolaan arsip sampai dengan masalah pemusnahannya sebagaimana yang telah di bahas dalam table di atas, maka dapat disimpulkan bahwa protokol Notaris merupakan arsip negara berdasarkan ketentuan Undang-Undang Jabatan Notaris, namun bukan kriteria arsip yang dimaksud dalam Undang-Undang Kearsipan. Kedua arsip itu merupakan dua buah jenis arsip yang berbeda, sehingga ketentuan dalam Undang-Undang Kearsipan tidak dapat diberlakukan terhadap protokol Notaris.

\section{Pertanggungjawaban Ahli Waris Notaris yang Menghilangkan Protokol Notaris}

Kewajiban Notaris yang diemban sampai selesai masa tugas jabatannya adalah menyimpan protokol Notaris. Berdasarkan Pasal 1 ayat (13) Undang-Undang Jabatan Notaris Perubahan menjelaskan bahwa Protokol Notaris adalah kumpulan dokumen yang merupakan arsip negara yang harus disimpam dan dipelihara Notaris sesuai dengan peraturan perundang-undangan. Dalam menyimpan akta-akta atau kumpulan dokumen notaris dilakukan sampai batas usia yang telah ditentukan oleh undangundang. Namun untuk protokol notaris, tidak hanya disimpan sampai berakhir masa jabatan, namun juga wajib bagi Notaris (dan atau ahli warisnya) untuk menyerahkan protokol tersebut kepada Notaris yang ditunjuk oleh Majelis Pengawas Daerah (untuk selanjutnya disebut MPD) dalam hal Notaris: ${ }^{8}$

\footnotetext{
${ }^{8}$ Pasal 62 Undang-Undang Jabatan Notaris
} 
1. Meninggal dunia;

2. Telah berakhir masa jabatannya;

3. Minta sendiri;

4. Tidak mampu secara rohani dan /atau jasmani untuk melaksanakan tugas jabatan sebagai Notaris secara terus menerus lebih dari 3 (tiga) tahun;

5. Diangkat menjadi pejabat negara;

6. Pindah wilayah jabatan;

7. Diberhentikan sementara; atau

8. Diberhentikan dengan tidak hormat.

Kewajiban penyerahan protokol Notaris ketika Notaris tersebut meninggal dunia diatur oleh Pasal 35 ayat (1) Undang-Undang Jabatan Notaris Perubahan yang menentukan bahwa Apabila Notaris meninggal dunia suami/istri atau keluarga sedarah dalam garis lurus keturunan semenda sampai derajad kedua wajib memberitahukan kepada Majelis Pengawas Daerah. Kewajiban suami/istri atau keluarga sedarah dalam garis lurus keturunan semenda sampai derajad kedua untuk memberitahukan kepada MPD terkait meninggalnya Notaris ini, juga diikuti dengan ketentuan Pasal 63 ayat (2) Undang-Undang Jabatan Notaris Perubahan yang menentukan bahwa dalam hal terjadi sebagaimana dimaksud Pasal 62 huruf a (penyerahan protokol notaris dikarenakan meninggalnya notaris), penyerahan Protokol Notaris dilakukan oleh ahli waris Notaris kepada Notaris lain yang ditunjuk oleh Majelis Pengawas Daerah.

Kewajiban yang diberikan kepada ahli waris notaris untuk menyerahkan protokol Notaris, ternyata tidak disertai dengan sanksi hukum yang jelas jika suami/istri atau keluarga sedarah dalam garis lurus keturunan semenda sampai derajad kedua tersebut tidak memenuhi kewajibannya. Oleh karena itu, dalam hal terjadi pelanggaran, tidak ada upaya hukum yang dapat dilakukan terhadap ahli waris berdasarkan Undang-Undang Jabatan Notaris. Sebagaimana dalam praktik yang dikaji penelitian ini, terjadi kasus dimana ahli waris tidak memberitahukan kematian Notaris (pewaris) kepada MPD, dan karena kelalaiannya ahli waris juga melakukan penjualan arsip atau kumpulan dokumen (protokol notaris) yang dimiliki oleh Notaris yang meninggal tersebut kepada orang lain. ${ }^{9}$

Ahli waris beranggapan bahwa Protokol Notaris itu hanya kumpulan kertas dan tidak memiliki nilai. Tidak menutup kemungkinan, ahli waris dapat berkilah bahwa mereka tidak mengetahui kewajibannya sebagai ahli waris dari seorang Notaris untuk memberitahukan kepada MPD atas kematian Notaris tersebut dan tetap menjaga protokol notaris.

Meskipun tidak diatur secara tegas mengenai bentuk tanggungjawan ahli waris atas tindakannya tersebut dalam Undang-Undang Jabatan Notaris maupun dalam Undang-Undang Jabatan Notaris Perubahan karena kedua undang-undang tersebut hanya mengatur terkait subjek yang mempunyai jabatan notaris, tidak berarti bahwa ahli waris dapat terbebas dari tanggungjawab dan melupakan kesalahan yang telah dilakukan serta tidak dapat kenai suatu sanksi.

Sejak 1919, perbuatan melawan hukum telah diartikan secara luas, yaitu mencakup: 10

\footnotetext{
${ }^{9}$ Data diperoleh dari kasus yang ditangani oleh MPD Wilayah Malang pada 2014.

${ }^{10}$ Munir Fuady, Perbuatan Melawan Hukum, PT. Citra Aditya Bakti, Bandung, 2013, hlm. 6.
} 
1. Perbuatan yang bertentangan dengan hak orang lain;

2. Perbuatan yang bertentangan dengan kewajiban hukumnya sendiri;

3. Perbuatan yang bertentangan dengan kesusilaan;

4. Perbuatan yang bertentangan dengan kehati-hatian atau keharusan dalam pergaulan masyarakat yang baik.

Berdasarkan pemaknaan perbuatan melawan hukum di atas, ahli waris yang menghilangkan protokol Notaris telah melakukan perbuatan yang bertentangan dengan kewajiban hukumnya sendiri yaitu kewajiban yang telah diatur Pasal 35 ayat (1) dan (2) jo. Pasal 63 ayat (2) Undang-Undang Jabatan Notaris Perubahan.

Selain itu, jika melihat kepada ketentuan Undang-Undang Kearsipan. Sesuai dengan pembahasan sebelumnya, protokol notaris bukanlah arsip negara sebagaimana yang ditentukan oleh Undang-Undang Kearsipan, sehingga segala ketentuan dan sanksi yang ditentukan dalam Undang-Undang Kearsipan juga tidak dapat diterapkan terhadap kesalahan ahli waris yang menghilangkan protokol minuta akta.

Berdasarkan pemaparan tersebut di atas, dapat disimpulkan bahwa:

1. Ahli waris tidak dapat dimintai pertanggungjawaban berdasarkan Undang-Undang Jabatan Notaris dan Undang-Undang Kearsipan. Hal ini dikarenakan UndangUndang Jabatan Notaris hanya mengatur mengenai orang-orang yang berprofesi sebagai Notaris. Majelis Pengawas Notaris tidak memiliki kewenangan untuk meminta pertanggungjawaban ahli waris karena mereka bukanlah orang yang berprofesi sebagai Notaris. Selain itu, Undang-Undang Jabatan Notaris sendiri tidak mengatur adanya sanksi kepada ahli waris Notaris atas tidak dipenuhinya kewajiban mereka berdasarkan Pasal 35 Jo. Pasal 63 Undang-Undang Jabatan Notaris Perubahan. Di sisi lain, protokol Notaris sendiri bukanlah arsip negara sebagaimana ketentuan Undang-Undang Kearsipan, sehingga sanksi yang ditentukan oleh Undang-Undang Keasipan juga tidak dapat diberikan kepada ahli waris yang menghilangkan protokol minuta akta.

2. Ahli waris bertanggungjawab kepada para pihak yang membuat akta autentik kepada Notaris (pewaris). Tanggungjawab ini adalah berdasarkan ketentuan Pasal 1365 KUHPerd tentang Perbuatan Melawan Hukum. Jika akta yang dibuat oleh para pihak menjadi kehilangan fungsinya sebagai alat bukti yang sah dan alat bukti yang sempurna (sebagai akta autentik) karena kesalahan dan kelalaian ahli waris menghilangkan protokol minuta akta, maka para pihak tersebut dapat meminta pertanggungjawaban ahli waris untuk memberikan ganti rugi kepada mereka berdasarkan Perbuatan Melawan Hukum.

\section{Kewenangan Majelis Pengawas Notaris dalam Penyelesaian Protokol Minuta Hilang}

Notaris dalam menjalankan tugas jabatannya secara institusional diawasi oleh 3 institusi berdasarkan Undang-Undang Jabatan Notaris yaitu Majelis Pengawas Notaris (MPN), Majelis Kehormatan Notaris (MKN) dan oleh Dewan Kehormatan Notaris (DKN) Ikatan Notaris Indonesia, ketiga institusi tersebut mempunyai kewenangan yang 
berbeda-beda sebagaimana yang tercantun dalam aturan yang mengatur masing-masing institusi tersebut. ${ }^{11}$

Majelis Pengawas Notaris yang selanjutnya disebut majelis pengawas adalah merupakan badan yang memiliki kewenangan dan kewajiban untuk melakukan pembinaan dan pengawasan terhadap Notaris. ${ }^{12}$ Majelis Pengawas Notaris dibentuk oleh Menteri untuk mendelegasikan kewenangan dalam mengawasi dan membina notaris yang meliputi perilaku dalam melaksanakan jabatan notaris. Pasal 67 ayat (1) UndangUndang Jabatan Notaris Perubahan menentukan bahwa yang melakukan pengawasan adalah menteri.

Dalam melaksanakan pengawasan tersebut Menteri membentuk Majelis Pengawas, Pasal 67 ayat (3) Undang-Undang Jabatan Notaris Perubahan menentukan Majelis Pengawas terdiri dari 9 orang, dengan unsur :

1. Pemerintah sebanyak 3 orang;

2. Organisasi Notaris sebanyak 3 orang; dan

3. Ahli atau akademisi sebanyak 3 orang.

Majelis Pengawas hanya berwenang melakukan pengawasan dan memberi sanksi kepada Notaris. Berdasarkan hal ini terlihat bahwa terbatasnya kewenangan yang dimiliki oleh Majelis Pengawas jika berkaitan dengan ahli waris yang bukan merupakan seorang Notaris. Dari beberapa kewenangan yang dimiliki Majelis Pengawas Notaris baik Daerah, Wilayah maupun Pusat di atas, baik yang tidak memerlukan rapat Majelis Pengawas maupun yang memerlukan rapat Majelis Pengawas, tidak ada satu kewenanganpun dari Majelis Pengawas untuk memberikan sanksi kepada ahli waris yang menghilangkan Protokol Minuta.

Di sisi lain, jika melihat kepada kewenangan Majelis Pengawas Notaris dalam memberikan perlindungan hukum kepada para pihak yang membuat akta autentik di hadapan Notaris yang meninggal dunia, ada beberapa kewenangan yang dapat memberikan perlindungan hukum tersebut meskipun tidak dalam bentuk mengganti protokol Minuta akta yang hilang. Pasal 58 jo Pasal 61 Undang-Undang Jabatan Notaris memberikan kewajiban administratif kepada Notaris untuk melaporkan kepada Majelis Pengawas Daerah berupa daftar akta, daftar surat di bawah tangan yang disahkan, daftar surat di bawah tangan yang dibukukan, dan daftar surat lain yang diwajibkan oleh Undang-Undang Jabatan Notaris paling lambat 15 hari pada bulan berikutnya. Pelaporan yang dilakukan Notaris dalam praktik biasanya dilakukan dengan melaporkan daftar yang disebut dengan buku repertorium. Buku tersebut berisi mengenai akta yang pernah dibuat oleh Notaris semasa mengemban jabatannya dan setiap bulan Notaris wajib melaporkan hal tersebut kepada Majelis Pengawas Daerah.

Daftar akta yang dilaporkan oleh Notaris inilah yang dapat digunakan oleh Majelis Pengawas Notaris untuk melindungi para pihak. Hal ini dikarenakan, daftar yang dilaporkan tersebut setidaknya akan memberikan informasi kepada Majelis Pengawas Daerah mengenai nomor urut akta, nomor bulanan, tanggal, sifat akta, dan nama semua

${ }^{11}$ Habib Adjie, Memahami: Majelis Pengawas Notaris (MPN) dan Majelis Kehormatan Notaris (MKN), Refika Aditama, Bandung, 2017, hlm. 3

${ }^{12}$ Pasal 1 ayat (2) Permenkumham Nomor 40 Tahun 2015. 
orang yang bertindak baik untuk dirinya sendiri maupun sebagai kuasa orang lain. Oleh karena itu, berkaca dari kasus ahli waris yang menghilangkan Protokol Notaris ini maka Majelis Pengawas Daerah wajib untuk memeriksa apakah repertorium selalu diisi setiap bulannya oleh Notaris dan dilaporkan kepada Majelis Pengawas Daerah atau tidak. Dalam hal terjadi protokol Notaris yang tidak lengkap atau hilang, ada beberapa hal yang wajib diperhatikan oleh Majelis Pengawas Daerah pada saat sebelum menerima protokol Notaris yang tidak lengkap dari ahli waris, yaitu sebagai berikut:

1. Mencocokkan protokol notaris yang tersisa dengan buku daftar akta notaris, buku klaper daftar akta, buku protes, buku legalisasi, buku klaper legalisasi, buku daftar wasiat, buku waarmerking.

2. Melihat data pada Majelis Pengawas Daerah, apakah Notaris tersebut selalu melakukan kewajiban untuk melaporkan setiap akta yang dibuatnya atau tidak.

Setelah melakukan 2 hal di atas, Majelis Pengawas Daerah kemudian membuat berita acara penerimaan sesuai dengan data yang diterimanya. Seperti misalnya apabila yang hilang adalah budel minuta pada bulan dan tahun tertentu, maka hal tersebut juga harus dicantumkan dalam berita acara. Tujuan menjelaskan secara rinci data yang diterima oleh Majelis Pengawas Daerah dalam berita acara tersebut adalah untuk dapat memberikan keterangan apabila ada pihak yang meminta salinan akta, bahwa akta tersebut pernah dibuat oleh Notaris yang bersangkutan, namun hilang sehingga salinan tidak bisa dikeluarkan utuh seperti layaknya minuta akta yang hilang tersebut.

Berdasarkan pembahasan tersebut, dapat disimpulkan bahwa Majelis Pengawas Notaris tidak memiliki kewenangan untuk memberikan sanki kepada ahli waris yang menghilangkan Protokol Minuta. Dalam hal terjadi protokol Notaris yang hilang atau tidak lengkap, maka Majelis Pengawas Daerah membuat berita acara mengenai hal itu secara terperinci dan lengkap. Berdasarkan daftar akta yang dilaporkan setiap bulan oleh Notaris, Majelis Pengawas Daerah dapat mengeluarkan surat keterangan untuk menyatakan bahwa akta yang disampaikan oleh para pihak memang pernah dibuat oleh Notaris yang bersangkutan. Pemberian surat keterangan ini dapat menjadi salah satu upaya perlindungan hukum yang dapat diberikan oleh Majelis Pengawas Notaris kepada Para Pihak yang aktanya kehilangan protokol Notarisnya.

\section{Penutup}

Berdasarkan penelitian tersebut di atas dapat disimpulkan:

1. Ada perbedaan yang cukup signifikan antara arsip negara yang diatur UndangUndang Kearsipan dengan Protokol Notaris sebagai arsip negara berdasarkan Undang-Undang Jabatan Notaris. Protokol Notaris merupakan arsip negara berdasarkan ketentuan Undang-Undang Jabatan Notaris, namun bukan kriteria arsip yang dimaksud dalam Undang-Undang Kearsipan. Kedua arsip itu merupakan dua buah jenis arsip yang berbeda, sehingga ketentuan dalam Undang-Undang Kearsipan tidak dapat diberlakukan terhadap protokol Notaris.

2. Ahli waris tidak dapat dimintai pertanggungjawaban berdasarkan Undang-Undang Jabatan Notaris dan Undang-Undang Kearsipan. Hal ini dikarenakan UndangUndang Jabatan Notaris hanya mengatur mengenai orang-orang yang berprofesi 
sebagai Notaris. Majelis Pengawas Notaris tidak memiliki kewenangan untuk meminta pertanggungjawaban ahli waris karena mereka bukanlah orang yang berprofesi sebagai Notaris. Di sisi lain, protokol Notaris sendiri bukanlah arsip negara sebagaimana ketentuan Undang-Undang Kearsipan, sehingga sanksi yang ditentukan oleh Undang-Undang Keasipan juga tidak dapat diberikan kepada ahli waris yang menghilangkan protokol notaris. Ahli waris bertanggungjawab kepada para pihak yang membuat akta autentik kepada Notaris (pewaris). Tanggungjawab ini adalah berdasarkan ketentuan Pasal 1365 KUHPerd tentang Perbuatan Melawan Hukum.

3. Majelis Pengawas Notaris tidak memiliki kewenangan untuk memberikan sanki kepada ahli waris yang menghilangkan Protokol Notaris. Dalam hal terjadi protokol Notaris yang hilang atau tidak lengkap, maka Majelis Pengawas Daerah membuat berita acara mengenai hal itu secara terperinci dan lengkap. Berdasarkan daftar akta yang dilaporkan setiap bulan oleh Notaris, Majelis Pengawas Daerah dapat mengeluarkan surat keterangan untuk menyatakan bahwa akta yang disampaikan oleh para pihak memang pernah dibuat oleh Notaris yang bersangkutan. Pemberian surat keterangan ini dapat menjadi salah satu upaya perlindungan hukum yang dapat diberikan oleh Majelis Pengawas Notaris kepada Para Pihak yang aktanya kehilangan protokol Notarisnya.

Dan berdasarkan hasil penelitian di atas, disarankan bahwa:

1. Hilangnya protokol Notaris oleh ahli waris menunjukan betapa pentingnya peranan Notaris dan Majelis Pengawas Notaris untuk memberikan pengajaran dan sosialisasi mengenai kewajiban ahli waris Notaris memberitahukan perihal kematian Notaris dan menyerahkan Protokol Notaris kepada Majelis Pengawas Notaris. Oleh karena itu, perlu mekanisme khusus untuk memberikan pemahaman yang komprehensif kepada ahli waris Notaris mengenai kewajiban mereka yang ada dalam UndangUndang Jabatan Notaris.

2. Salah satu bentuk kewenangan Majelis Pengawas Notaris adalah menerima laporan mengenai daftar akta yang dibuat oleh Notaris setiap bulannya. Kewenangan ini memiliki banyak sekali manfaat yang salah satunya adalah dalam hal hilangnya Protokol Notaris. Oleh karena itu, peranan Majelis Pengawas Notaris untuk secara rutin melakukan pemeriksaan kepada Notaris adalah salah satu bentuk perlindungan yang dapat diberikan kepada para pihak dan harus selalu ditingkatkan.

\section{Daftar Pustaka}

\section{Buku}

Sugiarto, Agus dan Teguh Wahyono, Manajemen Kerasipan Modern (Dari Konvensional ke Basis Komputer) Edisi Terbaru, Gava Media, Bandung, 2015.

Adjie, Habib, Hukum Notaris Indonesia, Refika Aditama, Bandung, 2008.

, Memahami: Majelis Pengawas Notaris (MPN) dan Majelis Kehormatan Notaris (MKN), Refika Aditama, Bandung, 2017.

Sanksi Perdata dan Administratif Terhadap Notaris Sebagai Pejabat Publik, Bandung: PT.Refika Aditama, 2008. 
Fuady, Munir, Perbuatan Melawan Hukum Pendekatan Kontemporer, Citra Aditya Bakti, Bandung, 2002.

Subekti, R.dan R. Tjitrosoedibio, Kamus Hukum, Pradnya Paramita, Jakarta, 2002.

Kitab Undang-Undang Hukum Perdata, Pradnya Pratama, Jakarta, 2008.

Rosalin, Sofia, Manajemen Arsip Dinamis, UB Press, Malang, 2017.

\section{Peraturan Perundang-Undangan:}

Kitab Undang-Undang Hukum Perdata (KUHPerd);

Undang-Undang Nomor 30 Tahun 2004 tentang Jabatan Notaris;

Undang-Undang Nomor 43 Tahun 2009 tentang Kearsipan;

Undang-Undang Nomor 02 Tahun 2014 tentang Perubahan atas Undang-Undang Nomor 30 Tahun 2004 tentang Jabatan Notaris;

Peraturan Pemerintah Nomor 28 Tahun 2012 tentang Pelaksanaan Undang-Undang Nomor 43 Tahun 2009 tentang Kearsipan;

Peraturan Menteri Hukum dan Hak Asasi Manusia Nomor 40 Tahun 2015 tentang Susunan Organisasi, Tata Cara Pengangkatan Anggota, Pemberhentian Anggota, dan Tata Kerja Majelis Pengawas, Majelis Pengawas Daerah;

Peraturan Menteri Hukum dan Hak Asasi Manusia Nomor 15 Tahun 2020 tentang Tata Cara Pemeriksaan Majelis Pengawas Terhadap Notaris 